\title{
Qianliening capsules influence the apoptosis of benign prostatic hyperplasia epithelial-1 cells by regulating the extracellular matrix
}

\author{
JIANHENG ZHOU ${ }^{1}$, JIUMAO LIN ${ }^{2}$, LIYA LIU ${ }^{2}$, YUQING ZHENG ${ }^{1}$ and ZHENFENG HONG ${ }^{2}$ \\ ${ }^{1}$ Department of Integrative Medicine, Fujian University of Traditional Chinese Medicine; \\ ${ }^{2}$ Academy of Integrative Medicine, Fujian University of Traditional Chinese Medicine, \\ Fuzhou, Fujian 350122, P.R. China
}

Received April 24,2014; Accepted December 3, 2014

DOI: $10.3892 / \mathrm{mmr} .2015 .3206$

\begin{abstract}
The present study investigated whether Qianliening capsules (QC) affected the apoptosis of benign prostatic hyperplastia epithelial (BPH-1) cells by regulating the extracellular matrix (ECM). The levels of fibronectin (FN) and collagen IV were determined in the culture medium of BPH-1 cells maintained in normal medium and of BPH-1 cells maintained in an environment rich in FN and collagen IV using an enzyme-linked immunosorbent assay. Reverse transcription quantitative polymerase chain reaction and western blot analysis were performed to determine the mRNA and protein expression levels of FN, collagen IV, B-cell lymphoma 2 (Bcl-2), Bcl-2-associated $\mathrm{X}$ protein (Bax) and cyclin D1, respectively. The cell morphology and viability were determined using light microscopy and an MTT assay and cell apoptosis was detected by annexin $\mathrm{V}$ staining. The results demonstrated that FN and collagen IV affected the apoptotic response of the BPH-1 cells, QC treatment significantly reduced the levels of FN and collagen IV secreted by the cells into the culture medium $(\mathrm{P}<0.01)$, inhibited the mRNA and protein expression levels of FN, collagen IV, Bcl-2 and cyclin D1 and promoted the mRNA and protein expression of Bax. Therefore, one of the mechanisms underlying the anti-BPH action of QC involves promoting apoptosis by regulating the expression of the extracellular matrix.
\end{abstract}

Correspondence to: Professor Zhenfeng Hong, Academy of Integrative Medicine, Fujian University of Traditional Chinese Medicine, 1 Huatuo Road, Minhou Shangjie, Fuzhou, Fujian 350122, P.R. China

E-mail: zfhong1953@163.com

Abbreviations: $\mathrm{BPH}-1$, benign prostatic hyperplasia epithelial-1; QC, Qianliening capsule; FN, fibronectin; ECM, extracellular matrix; PBS, phosphate-buffered saline

Key words: Qianliening capsule, extracellular matrix, apoptosis, proliferation, benign prostatic hyperplasia, fibronectin, collagen IV

\section{Introduction}

Multiple factors contribute to the pathogenesis of benign prostatic hyperplasia (BPH) (1-5). The biological roles of the extracellular matrix (ECM) in adhesion, growth and proliferation have been investigated extensively (6). The ECM not only serves as an external environment for the physiological activities of cells, but supports the intercellular signal transduction pathways involved in multiple physiological and pathological processes $(7,8)$. Qianliening capsule (QC) is a traditional Chinese medicine developed at the People's Hospital of Fujian University of Traditional Chinese Medicine (cat. no. Z20110009). QC was developed based on the understanding of $\mathrm{BPH}$ in traditional Chinese medicine of the pathology of $\mathrm{BPH}$. The predominant actions of QC include heat-clearing and detoxification, promoting blood circulation, removing blood stasis, toning up the kidney and nourishing vitality (termed 'replenishing qi' in Chinese) (9). Our previous studies revealed that QC inhibits the proliferation of benign prostatic hyperplastia epithelial cell line 1 (BPH-1) cells, promotes their apoptosis and regulates the effects of certain cytokines (10-13) to exert its therapeutic effects on BPH. However, the specific mechanisms underlying the therapeutic effectiveness of QC remain to be elucidated. The present study investigated the effect of QC on the ECM to evaluate its effects on apoptosis and proliferation in the BPH-1 cells and examined the association between the ECM and BPH-1 apoptosis to reveal the potential mechanism underlying the therapeutic effect of $\mathrm{QC}$ in $\mathrm{BPH}$.

\section{Materials and methods}

Drugs and reagents. QC (Food and Drug Administration approval no. Z20110009), a capsule containing five Chinese products, was provided by the Academy of Pharmacology of Fujian University of Traditional Chinese Medicine (Fujian, China) (14,15). The powder inside the capsule was dissolved in $40 \%$ DMSO to a concentration of $50 \mathrm{mg} / \mathrm{ml}$ (Sigma-Aldrich, St. Louis, MO, USA) and stored at $4^{\circ} \mathrm{C}$. Human collagen IV (Sigma-Aldrich), fibronectin (FN; Sigma-Aldrich) and an enzyme-linked immunosorbent assay 
(ELISA) kit was obtained from Shanghai XiTang Biological Technology Co., Ltd. (Shanghai, China). RPMI-1640, trypsin and fetal bovine serum (FBS) were purchased from HyClone (Logan, UT, USA). MTT was obtained from Sigma-Aldrich. The reverse transcription (RT), TRIzol and quantitative polymerase chain reaction (PCR) reagents $(5 \mathrm{X}$ reaction buffer, $10 \mathrm{mM}$ deoxyribonucleotide triphosphate mix, RevertAid ${ }^{\mathrm{TM}} \mathrm{M}-\mathrm{MuLV}$ reverse transcriptase) were purchased from Invitrogen Life Technologies (Carlsbad, CA, USA). Taq polymerase and the RNase inhibitor, ribonuclease inhibitor, were provided by Takara Bio, Inc. (Otsu, Japan) and primers were synthesized by Shanghai Yingjun Biological Technology Co., Ltd. (Shanghai, China). The Annexin V-fluorescein isothiocyanate (FITC) Apoptosis Detection kit was provided by BD Biosciences (San Jose, CA, USA). Polyclonal anti-rabbit primary antibodies against collagen IV (1:1,000; ab6581) was purchased from Abcam, Cambridge, MA, USA; FN (1:1,000; 610077) was purchased from BD Biosciences and B-cell lymphoma 2 (Bcl-2; 1:1,000, \#2876), Bcl-2-associated X protein (Bax; 1:1,000; \#2772) and cyclin D1 (1:1,000; \#2922) were obtained from Cell Signaling Technology, Inc., Danvers, MA, USA). The mouse anti-rabbit secondary IgG antibody (3,3'-diaminobenzidine) was obtained from Hebei Bohai Biotechnology Development Co., Ltd. (Hebei, China).

Cell lines. The BPH-1 cell line was provided by the Institute for Molecular Biology, College of Life Sciences, Nankai University, Tianjin, China.

Culture of BPH-1 cells. The BPH-1 cells were cultured in RPMI-1640 medium containing $10 \%$ (v/v) FBS, $100 \mathrm{U} / \mathrm{ml}$ penicillin and $100 \mu \mathrm{g} / \mathrm{ml}$ streptomycin (HyClone, SV30010; GE Healthcare Life Sciences, Little Chalfont, $\mathrm{UK}$ ), at $37^{\circ} \mathrm{C}$ in a humidified incubator with $5 \% \mathrm{CO}_{2}$. The cells were subcultured at $80-90 \%$ confluency.

Culture of BPH-1 cells in an environment rich in collagen IV and FN. Collagen IV was diluted to $1 \%$ in phosphate-buffered saline (PBS; HyClone, SH30256.01B) according to the manufacturer's instructions and 800-1,000 $\mu \mathrm{l} /$ well was added to 6 -well plates and incubated at $37^{\circ} \mathrm{C}$ for $4 \mathrm{~h}$. The wells were washed three times with PBS and the cells were seeded into the wells at a density of $2 \times 10^{5}$ cells/well. FN was diluted to $1 \%$ in PBS and 800-1,000 $\mu \mathrm{l} /$ well was added to 6 -well plates and incubated at $37^{\circ} \mathrm{C}$ for $4 \mathrm{~h}$, following by seeding of the cells into the wells $\left(2 \times 10^{5}\right.$ cells/well).

Determination of the concentrations of collagen IV and FN in the medium by ELISA. BPH-1 cells in the logarithmic growth phase were digested with trypsin and seeded into $100 \mu \mathrm{l}$ medium in 96 -well plates $\left(1 \times 10^{4}\right.$ cells/well), which were coated with either collagen IV or FN, or with PBS as a control group. Collagen IV was diluted to $1 \%$ in PBS according to the manufacturer's instructions, $20 \mu \mathrm{l} /$ well was added to 96-well plates and they were subsequently incubated at $37^{\circ} \mathrm{C}$ for $4 \mathrm{~h}\left(1 \times 10^{4}\right.$ cells/well $)$. The wells were washed three times with PBS and the cells were seeded into the wells. FN was diluted to $1 \%$ in PBS and $20 \mu \mathrm{l} /$ well was added to 96 -well plates $\left(1 \times 10^{4}\right.$ cells/well) and incubated at $37^{\circ} \mathrm{C}$ for
$4 \mathrm{~h}$, followed by seeding of the cells into the wells. After $24 \mathrm{~h}$ in culture, QC was added to the cells at different concentrations $(0,1.25,2.5$ or $5 \mathrm{mg} / \mathrm{ml})$ in duplicate for a further $24 \mathrm{~h}$. The cell culture medium was removed and the concentrations of collagen IV and FN were measured using an ELISA kit (Shanghai Xitang Biotechnology Co., Ltd), according to the manufacturer's instructions. The absorbance was measured at $490 \mathrm{~nm}$ using a microplate reader (Model ELX800; BioTek Instruments, Inc., Winooski, VT, USA) and the concentrations were calculated according to the standard curve.

Cell morphology observation. BPH-1 cells in the logarithmic growth phase were digested with trypsin and seeded into 6 -well plates at a density of $2 \times 10^{5}$ cells $/ \mathrm{ml}$ in $2 \mathrm{ml}$ medium. The cells were treated with various concentrations of QC for $24 \mathrm{~h}$ and cell morphology was observed using a DP70 phase-contrast microscope (Olympus Corporation, Tokyo, Japan). Images were captured at a magnification of x100.

Determination of cell viability by MTT assay. Following treatment with various concentrations of QC, the cells in each well were incubated with $0.5 \mathrm{mg} / \mathrm{ml} \mathrm{MTT}(100 \mu \mathrm{l})$ at $37^{\circ} \mathrm{C}$ for $4 \mathrm{~h}$. The medium in each well was removed and $100 \mu \mathrm{l}$ dimethyl sufoxide (Sigma-Aldrich) was added prior to incubation at room temperature for $10 \mathrm{~min}$ to resolve the crystals. The absorbance (A) was determined using a microplate reader at $570 \mathrm{~nm}$. The survival rate was calculated as follows: Survival rate $(\%)=\mathrm{A}_{\text {experiment }} / \mathrm{A}_{\text {control }} \times 100$.

Detection of the mRNA expression levels of collagen IV, FN, Bcl-2, Bax and cyclin DI by RT-PCR. BPH-1 cells in the logarithmic growth phase were digested with trypsin and seeded into $2 \mathrm{ml}$ medium in 6 -well plates $\left(2 \times 10^{5}\right.$ cells/well), which were coated with either collagen IV, FN or PBS (control group). After $24 \mathrm{~h}$, the cells were treated with various concentrations of QC for a further $24 \mathrm{~h}$. The mRNA expression levels of Bcl-2, Bax and cyclin D1 were then detected by RT-PCR in the uncoated samples and in the samples coated with either collagen IV or FN. The total RNA was isolated from the BPH-1 cells using TRIzol reagent. Oligo (dT)-primed RNA $(1 \mu \mathrm{g})$ was reverse-transcribed using SuperScript II Reverse Transcriptase (Promega Corporation, Madison, WI, USA) according to the manufacturer's instructions. The cDNA was used to determine the mRNA expression levels of collagen IV, FN, Bcl-2, Bax and cyclin D1 by PCR using Taq DNA polymerase (Fermentas, Hanover, MD, USA). GAPDH was used as an internal control. The sequences of the primers used for amplification were as follows: Collagen IV, forward 5'-ATC GGC TAC CTC CTG GTG A-3' and reverse 5'-GCT GAT GTG TGT GCG GAT GA-3' [annealing temperature $(\mathrm{Tm})=58^{\circ} \mathrm{C} ; 648 \mathrm{bp}$; FN, forward 5'-TGG ACC TTC TAC CAG TGC GAC-3' and reverse 5'-TGT CTT CCC ATC ATC GTA ACA C-3' (annealing $\mathrm{Tm}=58^{\circ} \mathrm{C} ; 451 \mathrm{bp}$ ); Bcl-2, forward 5'-CAG CTG CAC CTG ACG CCC TT-3' and reverse 5'-GCC TCC GTT ATC CTG GAT CC-3' (annealing $\mathrm{Tm}=55^{\circ} \mathrm{C} ; 362 \mathrm{bp}$ ); Bax, forward 5'-TGC TTC AGG GTT TCA TCC AGG-3' and reverse 5'-TGG CAA AGT AGA AAA GGG CGA-3' (annealing $\mathrm{Tm}=55^{\circ} \mathrm{C} ; 253 \mathrm{bp}$ ); cyclin D1, forward: 5'-TGG ATG CTG GAG GTC TGC GAG GAA-3' and reverse 5'-GGC TTC GAT CTG CTC CTG GCA GGC-3' 
(annealing $\mathrm{Tm}=55^{\circ} \mathrm{C} ; 537 \mathrm{bp}$ ) and GAPDH, forward $5^{\prime}$-GTC ATC CAT GAC AAC TTT GG-3' and reverse 5'-GAG CTT GAC AAA GTG GTC GT-3' (annealing Tm $=58^{\circ} \mathrm{C}$; $450 \mathrm{bp}$ ). The samples were analyzed using $1.5 \%$ agarose gel electrophoresis (HyClone). The DNA bands were visualized using a Gel Documentation system (Model Gel Doc 2000; Bio-Rad Laboratories, Inc., Hercules, CA, USA).

Detection of the protein expression levels of collagen IV, FN, Bcl-2, Bax and cyclin D1 by western blot analysis. The BPH- 1 cells $\left(2 \times 10^{5}\right.$ cells/well $)$ were seeded into $2 \mathrm{ml}$ medium in 6-well plates coated with either collagen IV, FN or PBS (control group). The cells were cultured for $24 \mathrm{~h}$ and were then treated with various concentrations $(0,1.25$, 2.5 or $5 \mathrm{mg} / \mathrm{ml}$ ) of QC. After $24 \mathrm{~h}$, the cells were lysed in lysis buffer (50 mM Tris-Cl, pH 6.8; $15 \mathrm{mM} \mathrm{NaCl}, 5 \mathrm{mM}$ EDTA, $0.5 \%$ NP-40 and $1 \mathrm{mM}$ PMSF; Sigma-Aldrich) and the total protein was extracted. In the collagen IV group and FN group, the proteins were dissolved in buffer for the concentration of the proteins, Bcl-2, Bax and cyclin D1, in the lysates to be determined. Following protein denaturation by boiling at $100^{\circ} \mathrm{C}$ for $5 \mathrm{~min}$, the lysates were subjected to polyacrylamide gel electrophoresis (SDS-PAGE) and the proteins were transferred onto a polyvinylidene fluoride membrane (EMD Millipore, Billerica, MA, USA). The membrane was blocked using $1 \%$ non-fat milk for $2 \mathrm{~h}$, prior to washing with Tris-buffered saline (TBS) with Tween 20 (Sigma-Aldrich) and incubation overnight at $4^{\circ} \mathrm{C}$ with the primary antibodies $(1: 1,000)$ against collagen IV, FN, Bcl-2, Bax, cyclin D1 and $\beta$-actin (Cell Signaling Technology, Inc.). The antibodies were diluted in 5\% w/v bovine serum albumin (Sigma-Aldrich), 1X TBS, $0.1 \%$ Tween ${ }^{\circledR} 20$ at $4^{\circ} \mathrm{C}$ with gentle shaking, overnight. The membrane was then incubated with horseradish-peroxidase-conjugated secondary antibody $(1: 25,000)$ at room temperature for $1 \mathrm{~h}$. The membrane was washed in TBS containing $0.25 \%$ Tween- 20 and then incubated with enhanced chemilluminescence solution (1:1; Technology Co., Ltd, Shanghai, China) at $25^{\circ} \mathrm{C}$ for $5 \mathrm{~min}$, followed by film exposure using a Bio-Rad Chemi Doc XRS+ system (Bio-Rad Laboratories, Inc.).

Detection of cell apoptosis. The cells were trypsinized (0.25\% trypsin without EDTA) and a cell suspension in RPMI-1640 was prepared. The cell density was adjusted to between $5 \times 10^{5}$ and $5 \times 10^{6}$ cells $/ \mathrm{ml}$. Aliquots $(1 \mathrm{ml})$ of the cell suspension were washed three times in PBS with centrifugation at $645 \mathrm{xg}$ for $10 \mathrm{~min}$ at $4^{\circ} \mathrm{C}$. Following the final wash, the cells were resuspended in $500 \mu \mathrm{L}$ binding buffer (Beyotime Institute of Biotechnology, Shanghai, China). Subsequently, $5 \mu \mathrm{l}$ annexin V-FITC and $5 \mu \mathrm{L}$ propidium iodide (PI) were added and the cells were incubated at room temperature for $15 \mathrm{~min}$. The cells were then analyzed using a FACScalibur flow cytometer (BD Biosciences).

Statistical analysis. Statistical analysis was performed using SPSS 12.0 software (SPSS, Inc., Chicago, IL, USA). Data are expressed as the mean \pm standard deviation. Statistical analyses of the data was performed using Student's t-test and analysis of variance. $\mathrm{P}<0.05$ was considered to indicate a statistically significant difference.

\section{Results}

Effect of $Q C$ on the expression levels of collagen $I V$ and $F N$ in BPH-1 cells. In the control group, QC significantly reduced the levels of collagen IV and FN in the BPH-1 cell culture medium $(\mathrm{P}<0.05$ and $\mathrm{P}<0.01$, respectively) and more marked inhibition was observed with higher concentrations of QC (Fig. 1A). Additionally, treatment with QC markedly inhibited the mRNA and protein expression levels of collagen IV and FN in the BPH-1 cells (Fig. 1B and C).

Effect of QC on the morphology and viability of the BPH-I cells. On visualization under an inverted microscope, the BPH-1 cells in the collagen IV and FN groups were rhombic, evenly dense and had clear nuclei. The cell density and extensibility were higher and the number of apoptotic cells were lower in the collagen IV and FN groups compared with the control group. The morphological integrity and the number of cells decreased with increasing concentrations of QC (Fig. 2A-C). The MTT assay revealed that the viability of the BPH-1 cells coated with either collagen IV or FN were significantly higher compared with the uncoated ECM group $(\mathrm{P}<0.05$ and $\mathrm{P}<0.01$, respectively; Fig. $3 \mathrm{~A})$. In addition, increasing concentrations of QC decreased the viability of the BPH-1 cells in all three groups, to different extents $(\mathrm{P}<0.05$ or $\mathrm{P}<0.01$, respectively; Fig. $3 \mathrm{~B})$, particularly in the uncoated ECM group.

Effect of QC on the proliferation and apoptosis of BPH-1 cells. The annexin V-FITC staining indicated that, in the absence of QC, the apoptotic index of the cells coated with either collagen IV or FN decreased significantly compared with the uncoated ECM control group. In each group, the apoptotic index increased as the concentration of QC increased (Fig. 4A-C). RT-PCR and western blot analysis revealed that the mRNA and protein expression levels of Bax in the cells coated with either collagen IV or FN were significantly lower compared with those in the uncoated ECM group and increased with increasing concentrations of QC. However, the levels of Bcl-2 and cyclin D1 were markedly higher in the cells coated with either collagen IV or FN compared with those in the uncoated ECM group. In each group, the mRNA and protein expression levels of Bcl-2 and cyclin D1 decreased as the concentration of QC increased (Figs. 5 and 6).

\section{Discussion}

Multiple factors contribute to the pathogenesis of BPH. An increasing number of studies have focused on the role of the ECM in the adhesion, growth and proliferation of cells (6). The ECM not only serves as an external environment for the physiological activities of cells, but supports the intercellular signal transduction pathways involved in multiple pathological and physiological processes $(7,8)$. The ECM is involved in the pathogenesis of BPH in the following ways: The ECM, together with proliferating cells, causes changes in the morphology and physiological functions of the prostate $(16,17)$; androgen, estrogen and their receptors regulate active peptides in tissues (18) and stimulate cells to produce 
A
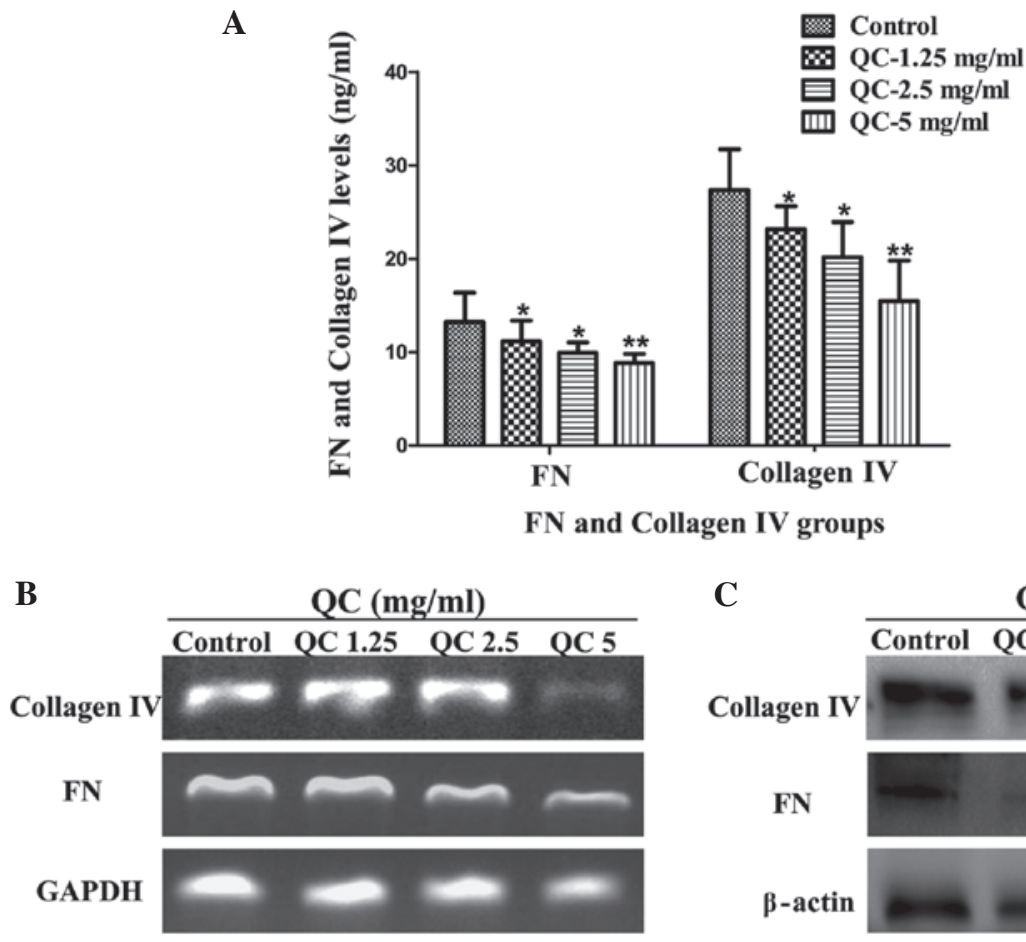

C

$\mathrm{QC}(\mathrm{mg} / \mathrm{ml})$

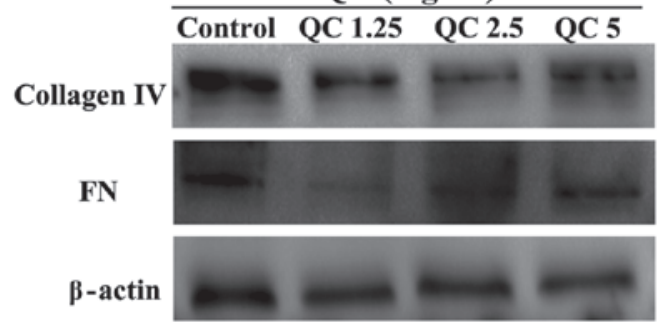

D

$\mathrm{FN}(\mathrm{Hu})$

Collagen $N$
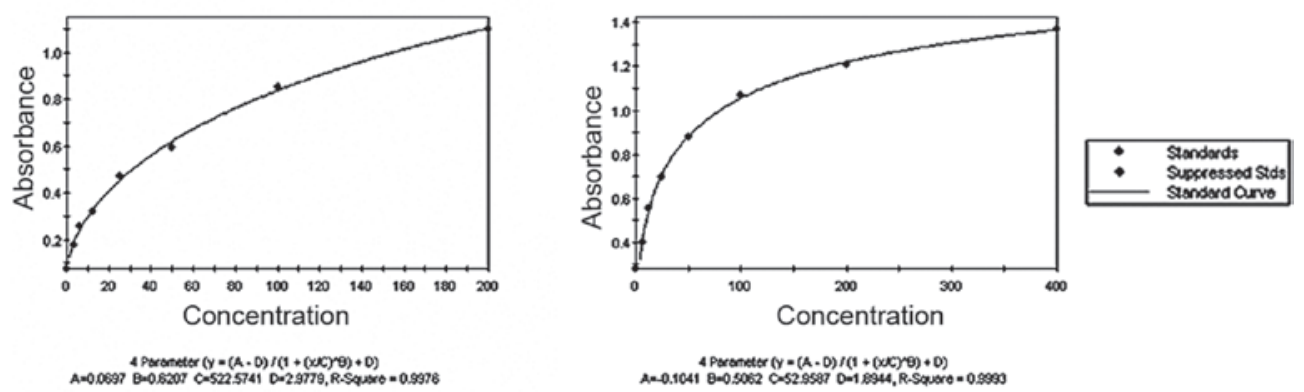

Figure 1. Effect of QC on the expression levels of collagen IV and FN in the BPH-1 cells. (A) Effect of QC on the levels of FN and collagen IV in the cell culture medium. (B) Effect of QC on the mRNA and (C) protein expression levels of collagen IV and FN in the BPH-1 cells. (D) Standard curves for FN and collagen IV in the cell culture medium, determined by ELISA. ${ }^{*} \mathrm{P}<0.05$ and ${ }^{* *} \mathrm{P}<0.01$, compared with the control group. BPH-1, benign prostatic hyperplasia epithelial cell line 1; QC, Qianliening capsule; FN, fibronectin; control; $0 \mu \mathrm{g} / \mathrm{ml}$ QC).

different components of the ECM (19) and the ECM interacts with hormones and growth factors to increase the sensitivity of prostate cells to androgen and growth factors, which alters the morphology of fibroblasts, sensitivity to hormones and gene expression (20). The ECM can also regulate the secretion of different growth factors, including transforming growth factor- $\beta$, by the prostate cells to regulate prostate cell growth in a paracrine or autocrine manner (17).

QC is a compound found in Chinese herbs, including rhubarb, leeches, astragalus and achyranthes $(14,15)$. Previous studies have demonstrated that QC inhibits the proliferation of BPH cells, induces apoptosis and regulates the expression of certain cytokines $(11-13,16)$, thus exerting a therapeutic effect on BPH. However, the mechanisms underlying the therapeutic effects of QC on BPH remain to be elucidated.

The present study provided further evidence that components of the ECM are involved in the pathology of BPH. It was observed that BPH-1 cells in the collagen IV and FN groups were rhombic, exhibited even density and had clear nuclei. The cell density and extensibility in each of the groups were higher compared with the controls. In addition, the number of apoptotic cells in the collagen IV and FN groups were significantly lower compared with the control group. MTT assays revealed that QC markedly increased the viability of the BPH-1 cells in the collagen IV-and FN-coated groups compared with the uncoated ECM group. These results indicated that collagen IV and FN promoted the growth of BPH-1 cells, which was consistent with the findings of previous studies (21-23).

The levels of collagen IV and FN secreted into the medium and their mRNA and protein expression levels were significantly reduced in the QC-treated cells compared with the untreated cells. These results suggested that QC inhibited the synthesis and secretion of collagen IV and FN in the BPH-1 cells during the growth process. In addition, the apoptotic index of the BPH-1 cells increased and the proliferation rate decreased dose-dependently following treatment with QC Therefore QC inhibited the proliferation of BPH-1 cells and promoted their apoptosis. The present study also demonstrated that QC inhibited the mRNA and protein expression 
A

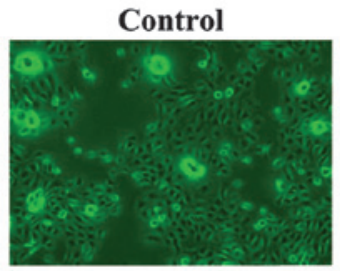

QC $1.25 \mathrm{mg} / \mathrm{ml}$

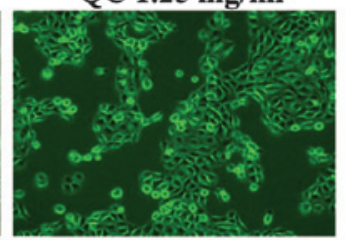

QC $2.5 \mathrm{mg} / \mathrm{ml}$
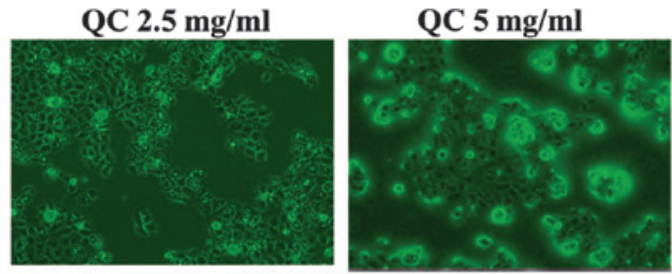

B

Uncoated $\mathbf{E C M}+\mathrm{QC}$ treatment

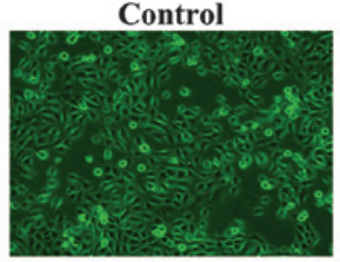

QC $1.25 \mathrm{mg} / \mathrm{ml}$

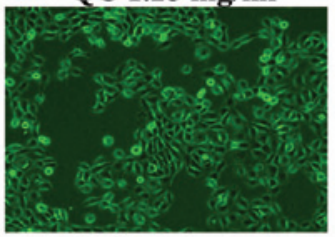

QC $2.5 \mathrm{mg} / \mathrm{ml}$

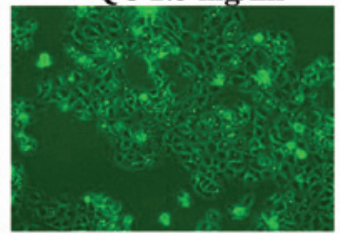

QC $5 \mathrm{mg} / \mathrm{ml}$

FN Coating $+Q C$ treatment

C
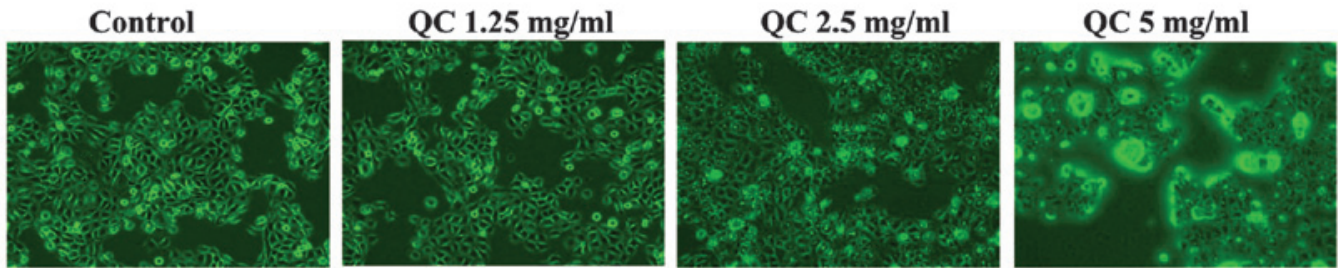

Collagen IV Coating $+Q C$ treatment

Figure 2. Effect of QC on the morphology of the benign prostatic hyperplasia epithelial (BPH-1) cells. The cells were observed under a phase-contrast microscope and representative images were captured at a magnification of $\mathrm{x} 100$. (A) Uncoated ECM cells were treated with various concentrations $(0,1.25,2.5$ or $5 \mathrm{mg} / \mathrm{ml}$ ) of QC. (B) Cells coated with FN and treated with various concentrations $(0,1.25,2.5 \mathrm{or} 5 \mathrm{mg} / \mathrm{mL}$ ) of QC. (C) Cells coated with collagen IV and treated with various concentrations $(0,1.25,2.5$ or $5 \mathrm{mg} / \mathrm{mL})$ of QC. QC, Qianliening capsule; FN, fibronectin; ECM, extracellular matrix.

A

\section{Uncoated ECM \\ 2. FN Coating \\ 3. Collagen IV coating}

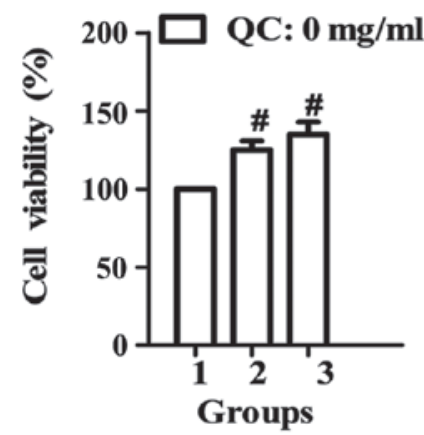

B

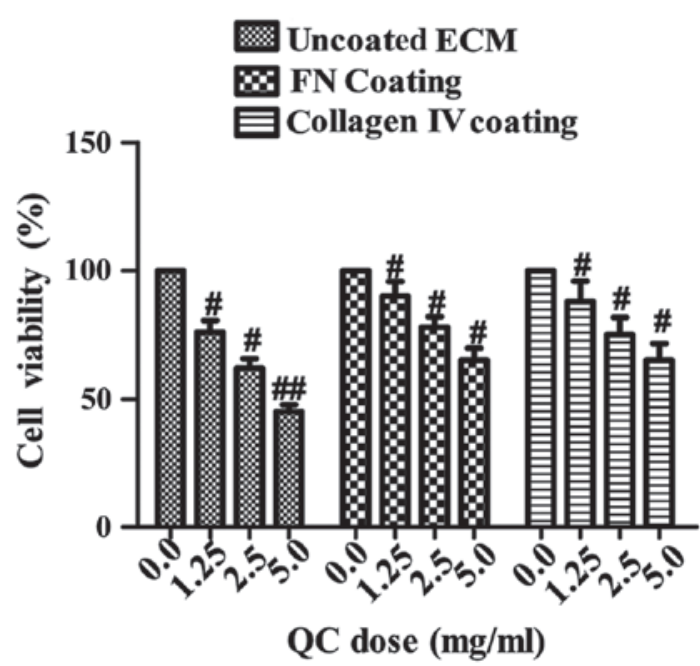

Figure 3. Effect of QC on BPH-1 cell viability. (A) BPH-1 cells without QC treatment. The cells with uncoated ECM were defined as the standard $\left(^{\sharp} \mathrm{P}<0.05\right.$, compared with standard). (B) BPH-1 cells were treated with various concentrations $(0,1.25,2.5 \mathrm{or} 5 \mathrm{mg} / \mathrm{ml})$ of QC. The $0 \mathrm{mg} / \mathrm{ml}$ group was defined as the standard $\left({ }^{*} \mathrm{P}<0.05\right.$ and ${ }^{\# /} \mathrm{P}<0.01$, compared with the standard). BPH-1, benign prostatic hyperplasia epithelial cell line 1; QC, Qianliening capsule; FN, fibronectin; ECM, extracellular matrix.

of cyclin D1, suggesting that QC can inhibit the cell cycle of $\mathrm{BPH}-1$ cells. However, the mechanism underlying this requires further investigation. As the ECM is important in regulating the proliferation and apoptosis of BPH cells during the pathogenesis of BPH $(16,17)$ and QC inhibited the secretion of FN and collagen IV during the growth of $\mathrm{BPH}-1$ cells, it was hypothesized that QC alters ECM production in BPH cells. The resulting effect on the proliferation and apoptosis of BPH cells may be one of the mechanisms underlying the therapeutic effects of QC on BPH. 
A
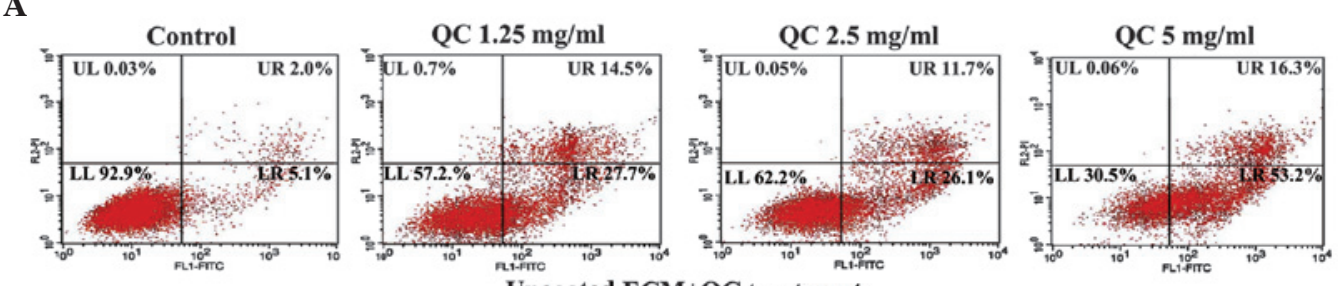

B

Uncoated ECM+QC treatment
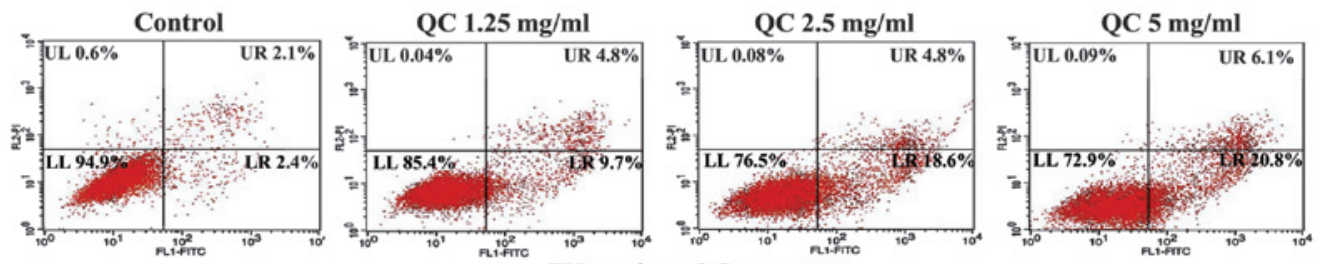

C

FN coating $+Q C$ treatment
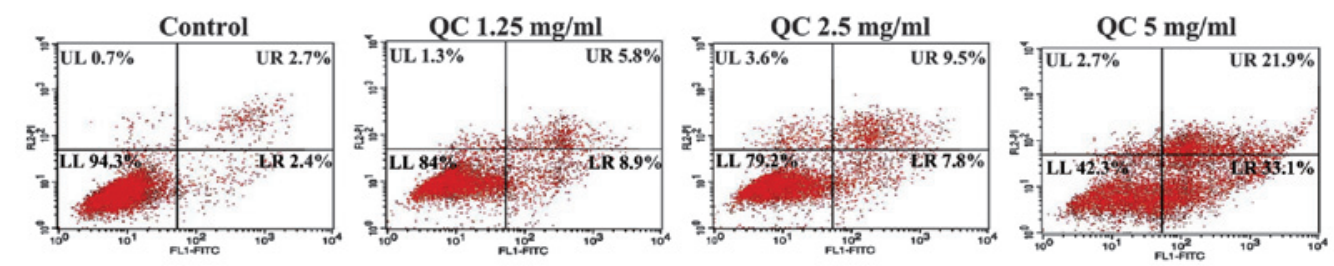

Collagen IV coating $+\mathrm{QC}$ treatment

Figure 4. Effect of QC on the number of apoptotic benign prostatic hyperplasia epithelial (BPH-1) cells. The rate of apoptosis induced by QC was assessed using annexin V-FITC/PI staining $24 \mathrm{~h}$ following treatment. The data are representative images from flow cytometric analysis. (A) Cells with uncoated ECM treated with QC at various concentrations $(0,1.25,2.5 \mathrm{or} 5 \mathrm{mg} / \mathrm{ml})$. (B) FN-coated cells treated with QC at various concentrations $(0,1.25,2.5 \mathrm{or} 5 \mathrm{mg} / \mathrm{ml})$. (C) Collagen IV-coated cells treated with QC at various concentrations $(0,1.25,2.5$ or $5 \mathrm{mg} / \mathrm{ml})$. QC, Qianliening capsule; FN, fibronectin; ECM, extracellular matrix.

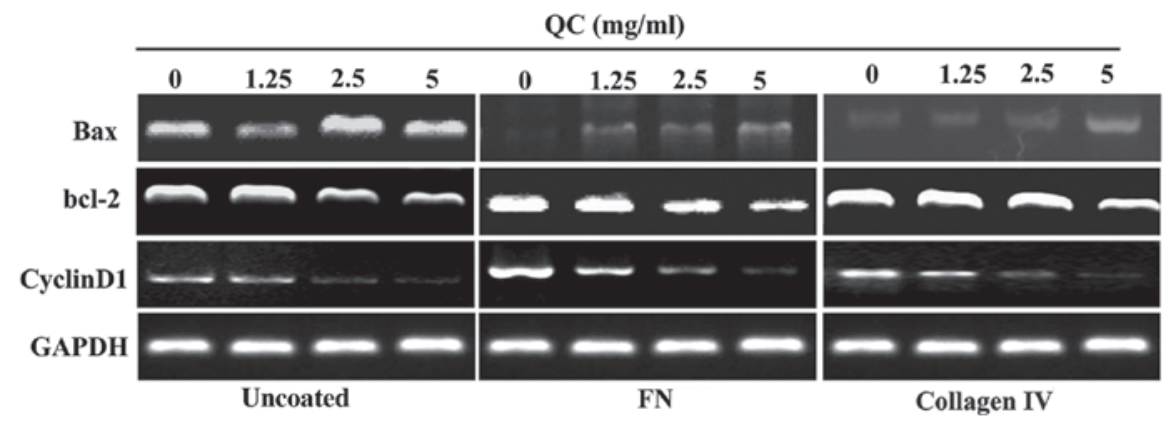

Figure 5. Effect of QC on the mRNA expression levels of Bcl-2, Bax and cyclin D1 in BPH-1 cells. The mRNA expression levels of Bcl-2, Bax and cyclin D1 in the BPH-1 cells were determined by reverse transcription quantitative polymerase chain reaction and visualized by electrophoresis. GAPDH was used as an internal control. Uncoated ECM cells and cells coated with either FN or collagen IV were treated with various concentrations $(0,1.25,2.5 \mathrm{or} 5 \mathrm{mg} / \mathrm{ml})$ of QC. QC, Qianliening capsule; FN, fibronectin; ECM, extracellular matrix; Bcl-2, B-cell lymphoma-2; BAX, Bcl-2 associated X protein; BPH-1, benign prostatic hyperplasia epithelial cell line 1 .

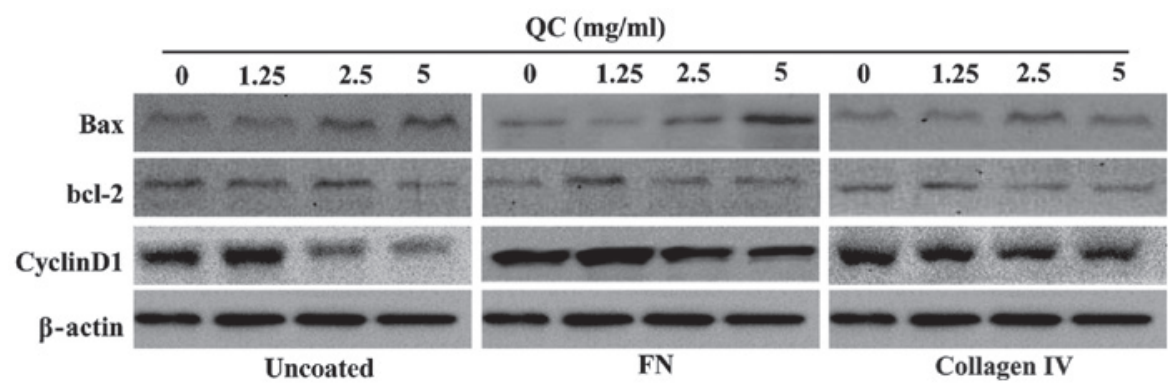

Figure 6. Effect of QC on the protein expression levels of Bcl-2, Bax and cyclin D1 in BPH-1 cells. QC treatment significantly increased the protein expression of Bax and reduced the protein expression levels of Bcl-2 and cyclin D1 in the BPH-1 cells. $\beta$-actin was used as the internal control for western blot analysis. Uncoated ECM cells and cells coated with either FN or collagen IV were treated with various concentrations $(0,1.25,2.5 \mathrm{or} 5 \mathrm{mg} / \mathrm{ml})$ of QC. QC, Qianliening Capsules; FN, fibronectin; Bcl-2, B-cell lymphoma-2; BAX, Bcl-2 associated X protein; BPH-1, benign prostatic hyperplasia epithelial cell line 1. 


\section{Acknowledgements}

This study was supported by the Nature Science Foundation of China (nos. 81373817 and 81273928), the Natural Science Foundation of Fujian Province of China (no. 2009J01169) and the Research Foundation of the Education Bureau of Fujian Province of China (no. JA09135).

\section{References}

1. Harman SM, Metter EJ, Tobin JD, Pearson J and Blackman MR Longitudinal effects of aging on serum total and free testosterone levels in healthy men. Baltimore Longitudinal Study of Aging. J Clin Endocrinol Metab 86: 724-731, 2001.

2. McNeal J: Pathology of benign prostatic hyperplasia. Insight into etiology. Urol Clin North Am 17: 477-486, 1990.

3. Untergasser G, Madersbacher S and Berger P: Benign prostatic hyperplasia: Age-related tissue-remodeling. Exp Gerontol 40 121-128, 2005.

4. Lucia MS and Lambert JR: Growth factors in benign prostatic hyperplasia: Basic science implications. Curr Urol Rep 9: 272-278, 2008.

5. Sciarra A, Mariotti G, Salciccia S, Autran Gomez A, Monti S, Toscano V and Di Silverio F: Prostate growth and inflammation. J Steroid Biochem Mol Biol 108: 254-260, 2008.

6. Von Der Mark K, Von Der Mark H and Goodman S: Cellular responses to extracellular matrix. Kidney Int 41: 632-640, 1992.

7. Raghow R: The role of extracellular matrix in postinflammatory wound healing and fibrosis. FASEB J 8: 823-831, 1994.

8. Shu CX and Cheng TM: Structure and function of extracellular matrix. Zhong Guo Xi Nan Guo Fang Yi Yao 11: 220-223, 2001 (In Chinese).

9. Cao W and Zhao AG: Prescription rules of Chinese herbal medicines in treatment of gastric cancer. Zhong Xi Yi Jie He Xue Bao 7: 1-8, 2009. (In Chinese)

10. Zhou JH, Lin JM, Xu W, Zhong XY, Zheng YQ, Hong ZF and Peng J: Qianliening capsule treats benign prostatic hyperplasia through regulating the expression of sex hormones estrogen receptor and androgen receptor. Afr J Pharm Pharmacol 6: 173-180, 2012.
11. Zhong XY, Lin JM, Zhou JH, Xu W, Hong ZF and Peng J: Qianliening capsule treats benign prostatic hyperplasia (BPH) by down-regulating the expression of PCNA, CyclinD1 and CDK4. Afr J Biotechnol 11: 7731-7737, 2012.

12. Zhou JH, Lin JM, Xu W, Zhong XY, Zheng YQ, Peng J. Xie JD and Hong ZF: Effects of Qianliening capsule on the expression of IL-10 and TNF- $\alpha$ in benign prostate hyperplasia. Chin Archives Trad Chin Med 28: 2657-2569, 2010.

13. Lin JM, Zhou JH, Zhong XY, Peng J, Xu W, Zheng HY, Zhao JY and Hong ZF: Effects of Qianliening capsule on the expression of EGF and EGFR in BPH Rats. Fujian J Trad Chin Med 41: 45-47, 2010.

14. Zheng HY, Xu W, Lin JM, Peng J and Hong ZF: Qianliening capsule treats benign prostatic hyperplasia via induction of prostatic cell apoptosis. Mol Med Rep 7: 848-854, 2013.

15. Lin JM, Zhou JH, Xu W, Zhong XY, Hong ZF and Peng J: Qianliening capsule treats benign prostatic hyperplasia via suppression of the EGF/STAT3 signaling pathway. Exp Ther Med 5: 1293-1300, 2013.

16. Li YM and Fang YH: Steroid hormones binding sites and extracellular matrix in the tissue of human benign prostatic hyperplasia. Chin J Urology 15: 269-271, 1994.

17. Li YM,Li YK, Hou SL,Fang SH,Li DQ and Liu XX: Extracellular matrix and transforming growth factor- $\beta$ in the tissue of benign prostatic hyperplasia. Chin J Urology 16: 421-422, 1995.

18. Lubrano C, Petrangeli E, Catizone A, Santonati A, Concolino G, Rombolá N, Frati L, Di Silverio F and Sciarra F: Epidermal growth factor binding and steroid receptor content in human benign prostatic hyperplasia. J Steroid Biochem 34: 499-504, 1989.

19. Roberts AB, McCune BK and Sporn MB: TGF- $\beta$ : Regulation of extrancellular matrix. Kidney Int 41: 577-559, 1992.

20. Freeman MR, Song Y, Carson DD, Guthrie PD and Chung LW: Extrancellular matrix and androgen receptor expression associated with spontaneous transformation of rat prostate fibroblast. Cancer Res 51: 1910-1916, 1991.

21. Janković MM and Kosanović MM: Fibronectin pattern in benign hyperplasia and cancer of the prostate. Dis Markers 25: 49-58,2008.

22. Djavan B, Lin V, Seitz C, Kramer G, Kaplan P, Richier J, Marberger $\mathrm{M}$ and McConnell: Elastin gene expression in benign prostatic hyperplasia. Prostate 40: 242-247, 1999.

23. Elliot SJ, Zorn BH, Mcleod DG, Moul JW, Nyberg L, Striker LJ and Striker GE: Pentosan polysulfate decreases prostate smooth muscle proliferation and extracellular matrix turnover. Prostate Cancer Prostatic Dis 6: 138-142, 2003. 